\title{
The impact of production shocks on maize markets in Ethiopia: implications for regional trade and food security
}

\author{
Mesay Yami ${ }^{1 *}$ (D) Ferdi Meyer ${ }^{2}$ and Rashid Hassan ${ }^{3}$
}

\author{
* Correspondence: mesay44@gmail. \\ com \\ ${ }^{1}$ Department of Agricultural \\ Economics, Extension and Rural \\ Development, University of Pretoria, \\ Pretoria, South Africa \\ Full list of author information is \\ available at the end of the article
}

\begin{abstract}
In this article, we demonstrated the dynamic impact of a bumper harvest and drought shocks on the maize market and on the trade regime in Ethiopia. Regional market integration of Ethiopia's white maize market with the South Sudan and Kenyan maize markets was also examined using cointegration analysis. Despite the renewed conflict in South Sudan, Addis Ababa maize market is cointegrated with Juba's maize market. The simulation analysis indicated that a $20 \%$ increase in maize yield could reduce the maize price by $81 \%$. This implies a decrease in the maize price level of 70\% (110 USD/t) below the export parity price. This makes maize exports profitable and shifts the trade regime from autarky to an export parity regime. On the other hand, the effect of a drought could increase maize prices by $61 \%$ in the short run (within the year). At the current market price, the domestic maize price is wandering between the border prices and it is unprofitable to export maize. Therefore, lifting the export ban, even during normal harvest seasons, would not do any harm to the domestic maize price.
\end{abstract}

Keywords: Export bans, Maize, Price stabilization, Production shocks, Traders

\section{Introduction}

In many African countries, the majority of households spend much of their expenditure on food items. ${ }^{1}$ As a result, high food prices present huge risks to the food security status of the region. In this instance, the question should not be whether African governments ought to intervene but, instead, how African governments could provide stability to grain prices without disrupting the domestic grain market environment. This is the challenge for many African countries that are responding with short-term stabilization interventions ${ }^{2}$ by allowing state marketing parastatals to undertake the price stabilization job. This traditional method of price stabilization is counterintuitive by impeding private traders and could make prices even more unstable and

\footnotetext{
${ }^{1}$ In 2011, the share of food consumption expenditures in the total consumption basket of Ethiopian households was $48 \%$ (see Worku et al. 2015).

${ }^{2}$ According to Jayne (2012), most countries in eastern and southern Africa follow the same discretionary state-led interventions in stabilizing grain markets. This form of intervention is characterized by unplanned and sudden export bans, and the issuing of government tenders for imports, which will be sold at subsidized prices in domestic markets without being well publicized to other stakeholders. This was the case for SubSaharan African countries such as Zambia, Ethiopia, Malawi, and Kenya.
} 
unpredictable (Minot 2014). Hence, African governments need to find effective means of managing food price risks.

African governments implemented a wide range of policy responses to cushion the impact of the 2007/2008 food crisis. The major policy responses included consumer support measures (safety net programs, reducing tariffs and domestic taxes, and releasing stocks) and trade and price control measures (export bans, price controls, and foreign exchange restrictions) (Demeke et al. 2009 and Demeke et al. 2014). However, most of these interventions were the result of panic and even worsened the situation in some African countries such as Malawi and Ethiopia (Jayne 2012). Minot (2011), in his comprehensive analysis, argued that African governments' 'fire-fighting' and ill-advised policy interventions contributed more to the food price spikes of 2008, rather than the price shocks from international market did.

Among trade policies, the major form of intervention comprises export bans. After the 2008 crisis period, Egypt, Malawi, Tanzania, Uganda, and Zimbabwe have imposed export bans. Zambia recently lifted its export ban on maize and maize products (Food and Agriculture Policy Decision Analysis Tool (FAPDA) 2017). Export bans can reduce domestic grain prices if export is profitable. However, there are diverging views on the impact of export bans on commodity market prices in Africa. Porteous (2012) and Chapoto and Jayne (2009) found no significant relationship between an export ban and domestic prices. The authors argue that in most African countries, export bans are implemented in response to soaring domestic grain prices. Unless the prices in other trading countries rise much faster, the higher domestic prices are likely to make exports unprofitable and the ban unnecessary. In contrast, Diao et al. (2013) found that the maize export ban in Tanzania reduced maize producer prices by 9 to 19\%. The experiences of Malawi, Zambia and Kenya have indicated that imposing an export ban may create uncertainty in the grain market. In these countries, the government has been actively involved in large-scale maize imports in response to supply shortfalls. In some cases, this is accompanied by a ban on private grain trade. Even when the ban is lifted, the uncertainty arising from involvement of state trading enterprises in the grain market makes it difficult for traders to profitably import maize. This uncertainty in the grain market environment is expected to contribute to food price spikes (Dorosh et al. 2009 and Dorosh et al. 2016).

The Ethiopian government has imposed an export ban on maize since 2008. From a food security perspective, the ban is expected to improve domestic maize consumption. However, the export ban may also create a disincentive for production if the domestic maize price decline below the export parity price. Since maize is a major food crop in Ethiopia, any price instability in the domestic maize market is expected to have an adverse effect on other tradable and non-tradable goods (Getnet 2009; Rashid 2011). Nevertheless, the export ban may also distort maize food availability and food security in the eastern Africa region. Maize is the major staple crop consumed and traded in the region. It is the second most-traded commodity, ${ }^{3}$ next to sesame, in the east African cross-border area. Owing to low maize yields, recurrent wars, and drought, several eastern Africa countries have relied on cross-border maize trade to fill their shortfalls.

${ }^{3}$ Maize commodities have constituted about $18 \%$ of the cross-border trade in the east Africa region (FEWS NET 2016) 
For instance, countries such as South Sudan, Kenya, Rwanda, and Somalia rely on formal and informal cross-border trade to import maize. These regional maize demands have been mainly met by imports from Uganda and Tanzania (FEWS NET 2016). However, maize production in Tanzania and Uganda does not exceed 3.5 million metric tons and is not enough to supply the regional demand. For instance, South Sudan alone imported more than 500 thousand tons in 2013 (Dorosh et al. 2016). Furthermore, Tanzania has tightened up on maize exports to the region, depending on domestic harvest conditions.

The Ethiopian maize market has the potential to supply affordable and quality white maize to eastern Africa countries. Several initiatives for maize exports to eastern Africa maize-deficit countries are being halted by the Ethiopian export ban. The World Food Program (WFP) initiative, the Purchase from Africans for Africans (PAA) programme, planned to procure maize from Ethiopian farmers for export to the rest of the eastern Africa countries (Nogales and Fonseca 2014). However, the frequent export ban has become the main roadblock to this initiative.

In order to solve this pressing issue, the Ethiopian government has requested the agricultural advising agency, Agricultural Transformation Agency (ATA), to advice government as to whether to lift the export ban in case of good harvest seasons. This article has attempted to support the on-going policy discussions by providing evidence on the likely impact of production shocks on the white maize market in Ethiopia. Existing literature have examined the impact of production shocks on the Ethiopian agriculture at one point in time, which is inadequate to capture the effect of weather-induced shocks across time (Dercon and Krishnan 2000; Dercon 2004; Deressa and Hassan 2010; Porter 2012; Thiede 2014; Hill and Porter 2017). In this article, we simulate the dynamic impact of production shocks (a bumper harvest and drought shocks) on the maize market in Ethiopia. Additionally, we examine the impact of these shocks on the maize trade regime in Ethiopia. The impact of production shocks are evaluated by comparing the outlook period maize price during a normal harvest season with hypothetical parity prices for a bumper harvest and a drought season. These production shocks were introduced into the model in the 2017 outlook period.

From a policy perspective, understanding the likely impact of weather-induced and good harvest shocks on the domestic maize market and on the regional maize trade patterns are critical to provide policy alternatives for the Ethiopian government to lift maize export bans and allow private sectors to export and import maize under different domestic maize harvest conditions. This will support rules-based state interventions in the domestic maize market and would reduce regional food insecurity by strengthening the ability of markets to provide access to affordable maize to poor households. Moreover, since Ethiopia has been a major recipient of food aid, food aid agencies would also benefit from a likely impact of weatherinduced shocks on maize production, market price, consumption, and government stocks.

This article is structured as follows. The "Data source and description" section describes price formation of a commodity and data sources. The "Concept of partial equilibrium modelling" and "Model structure" sections explain the analysis approaches. Findings of the study are discussed in section five. The "Conclusion and policy recommendations" section concludes and provides policy implications.

\section{Data source and description}

Ethiopia is largely self-sufficient in maize production. The self-sufficiency ratio for maize has fluctuated between 94 and 102\% implying that the country is trading at an 
autarky trade regime (Yami et al. 2017). Hence, domestic demand and supply dynamics are expected to determine maize price formation in Ethiopia. Full historical data for the supply and demand of maize components were obtained from the United States Department of Agriculture - Production, Supply and Demand (USDA-PSD). Domestic agricultural statistical data sources including the Central Statistical Agency of Ethiopia (CSA) and the Ethiopian Grain Trade Enterprise (EGTE) were also used to supplement the USDA's data. The historical data for the supply and demand components of maize commodity balance sheet range from 2001 to 2015 .

The maize crop in Ethiopia has shown tremendous growth, in both area harvested and productivity per hectare. On average, the maize area harvested expanded from 1.5 million ha to more than 2 million ha between 2001 and 2006 and 2012-2015. For the same period, the maize yield also increased substantially, from 1.86 to 2.9 tons $\mathrm{ha}^{-1}$. Because of this growth, maize production has been boosted recently, surpassing 6 million MT. During 2001-2006 and 2012-2015, maize production registered a 113\% growth rate, on average, from 2.8 million MT to 6.1 million MT (United States Department of Agriculture (USDA) 2015).

With regard to intra-country trade, there is evidence of maize exports from Ethiopia to other African countries since 2000 as shown in Table 1. Ethiopia exports maize grain and maize products (flour and bran) to major deficit maize markets of Sudan (former), Djibouti, and Kenya. Maize and maize products were exported consistently to Djibouti and Sudan (former). On the other hand, it was exported in only one specific year to Madagascar and Tanzania in 2004 and Kenya in 2011, respectively. The official maize export reached the highest of 23,332 tons in 2010. Similarly, negligible quantities of maize production, close to 2707 tons were exported in 2011. The 2010 and 2011 exports coincided with the 2-year period when the export ban on maize commodity had been lifted. The Ethiopian government lifted the export ban in July 2010. However, the lifting of the export ban did not last long as the government re-imposed the ban in March 2011.

Table 1 Maize export trends of Ethiopia to African countries (MT) (2000-2016)

\begin{tabular}{|c|c|c|c|c|c|c|c|c|c|c|}
\hline \multirow{2}{*}{$\begin{array}{l}\text { Export } \\
\text { destination }\end{array}$} & \multicolumn{10}{|c|}{ Export period } \\
\hline & 2000 & 2001 & 2002 & 2003 & 2004 & 2005 & 2006 & 2008 & 2010 & 2011 \\
\hline \multicolumn{11}{|l|}{ Djibouti } \\
\hline Flour & & & 11 & & & & & & & \\
\hline Maize & 335 & 311 & 1208 & 705 & 1290 & 696 & 422 & & 133 & 340 \\
\hline Maize bran & & & 93 & & & & & & & \\
\hline Maize flour & & 11 & & & & & & 10 & & \\
\hline \multicolumn{11}{|l|}{ Kenya } \\
\hline Maize & & & & & & & & & & 90 \\
\hline \multicolumn{11}{|l|}{ Madagascar } \\
\hline Maize & & & & & 2222 & & & & & \\
\hline \multicolumn{11}{|l|}{ Sudan (former) } \\
\hline Maize & & & & & & 1860 & 251 & & 23,199 & 2277 \\
\hline \multicolumn{11}{|l|}{ Tanzania } \\
\hline Maize & & & & & 5568 & & & & & \\
\hline Grand total (MT) & 335 & 322 & 1312 & 705 & 9080 & 2556 & 673 & 10 & 23,332 & 2707 \\
\hline
\end{tabular}


In general, the volume of maize export is negligible compared to the domestic production level. For instance, the aggregate volume of export during 2008-2011 was less than $1 \%$ of the country's maize production. Apart from the low volume of export, the export till 2008 was not a profitable one as the domestic wholesale price was wandering within the export and import parity prices (Rashid and Minot 2010). We believe that an official commercial export was not made during 20002008. Perhaps the exports that were noted were accounted for by the domestic procurements by the World Food Programme (WFP) for providing humanitarian assistance to other countries.

Time series data on producer and wholesale prices of white maize and sorghum commodities were obtained from the Food and Agricultural Organization of the United Nations (FAO). Real prices were used by deflating the nominal prices by the Consumer Price Index (CPI). Regarding the developments in wholesale maize price trends, the general trend in real price levels for maize and its close substitute, sorghum, indicated that both producer price levels experienced upward swings in 2007 and 2008. Recently, both producer and wholesale sorghum and maize prices have shown a declining trend (Fig. 1). This may have been attributed to the Ethiopian government policy responses to soaring food prices.

Monthly rainfall data was obtained from the National Meteorological Agency of Ethiopia (NMA). About 82\% of maize production is produced in Amhara and Oromia regions in Ethiopia (Rashid and Minot 2010). To this end, the rainfall patterns in these two regions would affect maize production in Ethiopia. From the Amhara region, rainfall data from Bahir Dar, Gondar, Dembecha, and DebreMarkos districts were used, while rainfall data from seven of the maize surplus producing districts of Oromia region, comprising Arsi-Negele, Bure (Illubabore zone), Bako, Jimma, Nekemete, Meki, and Ziway, were included in model estimation. The mean annual rainfall in the major maize producing districts is displayed in Table 2. The mean annual rainfall had fluctuated between $2096 \mathrm{~mm}$ in Nekemete to $692 \mathrm{~mm}$ in the Rift Valley moisture-stressed districts of Meki and Ziway. These rainfall amounts were favourable for maize production, as maize requires

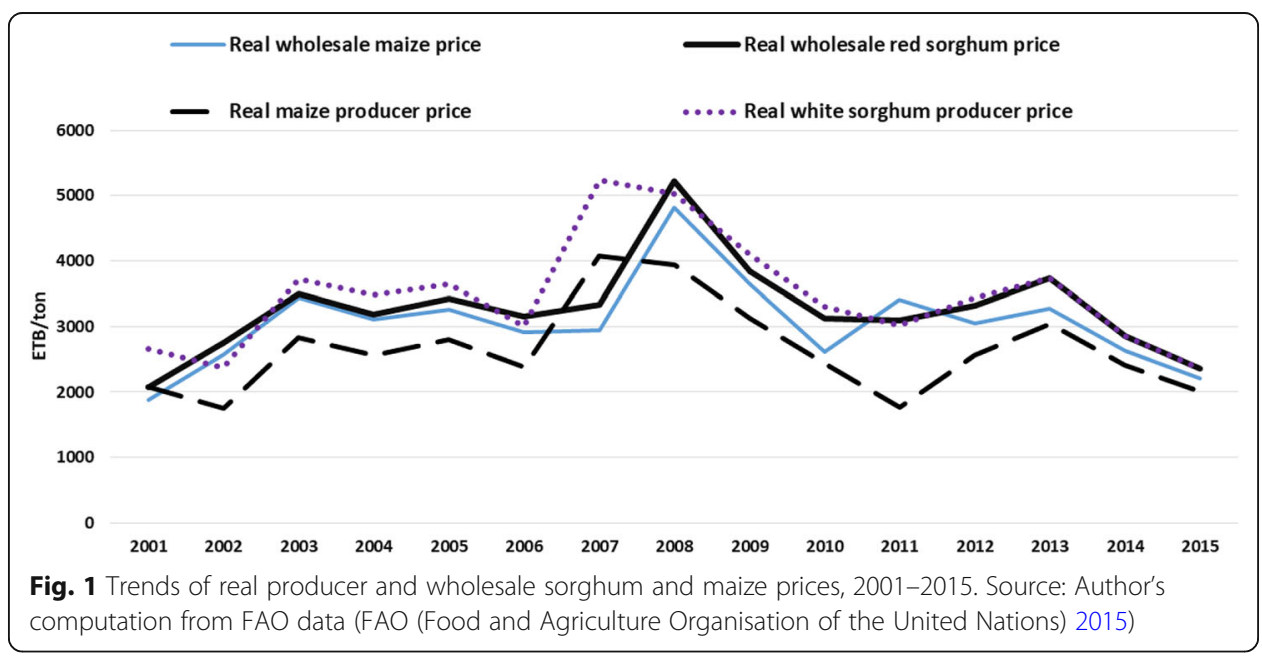


Table 2 Annual rainfall (mm) for major maize producing districts (1995-2014)

\begin{tabular}{lllllll}
\hline Regions & Districts & Elevations (masl) & Mean & Std. dev. & Min & Max \\
\hline Amhara & Bahir Dar & 1827 & 1365 & 304 & 635 & 1957 \\
& Gondar & 1973 & 1162 & 224 & 653 & 1761 \\
& Debre-Markos & 2446 & 1253 & 298 & 164 & 1590 \\
& Dembecha & 2117 & 1242 & 230 & 771 & 1640 \\
Oromia & Bako & 1650 & 1082 & 530 & 148 & 2381 \\
& Jimma & 1718 & 1466 & 282 & 831 & 1967 \\
& Nekemete & 2080 & 2096 & 232 & 1706 & 2551 \\
& Meki and Ziway & 1640 & 692 & 185 & 346 & 1042 \\
& Arsi-Negele & 1913 & 817 & 412 & 206 & 1486 \\
& Bure & 1750 & 976 & 442 & 315 & 1693 \\
\hline
\end{tabular}

Source: Author's calculation using NMA data (2015)

450 to $600 \mathrm{~mm}$ of precipitation per season. However, there were also drought years in Debre-Markos, Bako, and Arsi-Negele.

\section{Concept of partial equilibrium modelling}

The fundamental assumption of the partial equilibrium model is the neo-classical approach, which assumes that the balance between consumption and production in the economy is maintained by producers' and consumers' profit maximizing and utility motives (Garforth and Rehman 2006; Kotevska et al. 2013). Thus, the key behavioural assumptions of economic agents in partial equilibrium models are utility and profit maximization.

Typically, partial equilibrium models include supply, demand, trade, and price linkage blocks. The supply block consists of area harvested, yield, production, and beginning stocks. The demand block consists of human consumption, feed utilization and amount retained for seed, and ending stocks. Figure 2 displays the

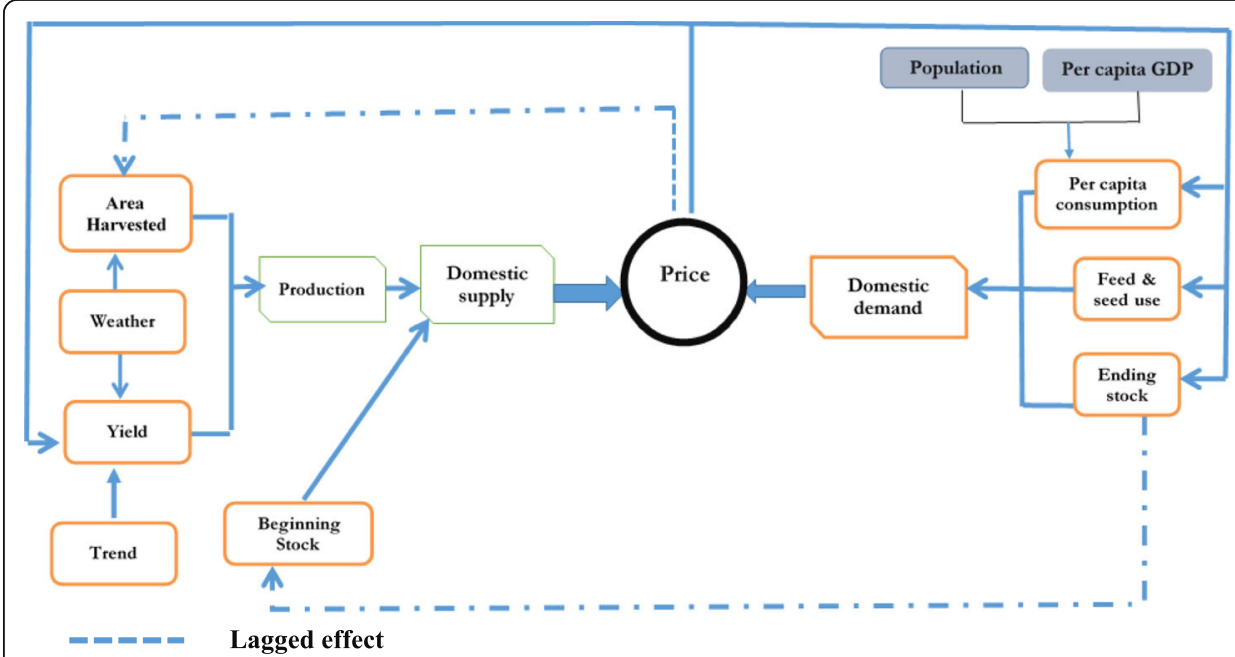

Fig. 2 White maize price formation in Ethiopia under autarky trade regime. Source: Adapted from Meyer et al. (2006) 
price formation for a commodity when a country is in an autarky trade regime. Since the maize industry in Ethiopia is trading in an autarky trade regime, this graphical explanation of the behavioural relationships can capture the features of white maize market price formation in Ethiopia. The broken lines indicate lagged relationships between variables. Farmers make their decisions to plant a crop based on lagged own price and prices of substitutes. Beginning stocks equals lagged ending stocks or inventory.

Farmers' decisions to grow maize start from land allocation decisions. Maize farmers have to make an initial decision on the size of maize area to be planted. Farmers' decisions on maize area allocation depend on own price, prices of substitutes, weather conditions, and prices of inputs. Measuring the effects of the abovementioned price and non-price related factors on farmers' land allocation decisions is called supply response analysis. One of the most important issues in agricultural development economics is supply response, since the responsiveness of farmers to economic incentives largely determines agriculture's dynamics and contribution to the economy. Furthermore, the response elasticity is also important for policy decision-making as it gives an indication of the factors that constrain farmers' responsiveness to output price changes. According to Tripathi (2008), the agricultural supply response represents change in agricultural output due to a change in agricultural output price. The concept of supply response is dynamic and different from supply function which is a static concept. The supply function describes a price quantity relation, where all other factors are held constant. The response relation is more general concept; it shows the change in quantity with changes in prices as well as supply shifters and, therefore, approximates to the long-run, dynamic concept of supply theory.

Maize is a stable food crop in Ethiopia. As a result, the Ethiopian government's main target is to maintain food self-sufficiency and improve the marketability of the commodity. Therefore, policies that encourage greater production of maize and the transition from a subsistence to a market-oriented farming system necessitate the carrying out of supply response studies. In annual agricultural crop production, farmers observe the output price after production has been obtained. As a result, farmers' planting decisions are made based on price expectations at harvesting time. Hence, producers' price expectations play a pivotal role in acreage allotment for annual crops. In general, two models are widely used to analyse the elasticities of supply response in annual agricultural crops. These approaches are the Nerlovian expectations and partial adjustment models. In the Nerlovian expectations model, farmers make their production decisions based on expectations of future prices. The assumption is that a rational farmer is more likely to respond to the price he or she expects, rather than to the price in the previous period, and the expected price will depend only to a limited extent on the actual price in the previous period.

On the other hand, the Nerlovian adjustment model assumes that farmers form their expectations about what will happen in the future based on what has happened in the past. Farmers, especially in developing countries, are facing problems in obtaining relevant market price information. Therefore, rational expectation behaviour is not relevant in the absence of future market 
information. Although the Ethiopian government has recently opened an exchange market, the trading of cereals including maize and wheat is relatively negligible, as compared with high-value exportable crops. Hence, this study has assumed that the Nerlovian adjustment model would be adequate for the Ethiopian maize market context.

According to Nerlove, the desired level of supply $\left(Q_{s}^{*}\right)$ can be expressed as a function of expected price and exogenous supply shifters:

$$
Q_{s}^{*}=\eta+\beta P_{t}+c Z_{t}
$$

where $Q_{s}^{*}$ is desired level of supply, $P_{t}$ is expected price, and $Z_{t}$ is a set of exogenous supply shifters such as technological progress, weather related factors, and so on.

Actual supply level $\left(S_{t}\right)$ may differ from the desired ones because of the adjustment lags of variable factors. Therefore, it is assumed that actual level of supply would only be a fraction $\delta$ of the desired level of supply.

$$
S_{t}=(1-\delta) S_{t-1}+\delta Q_{s}^{*}+\epsilon_{t}
$$

Farmers' expected price can be observed at harvest time. So, we have to formally describe how decision makers form expectations based on the knowledge of actual and past price and other observable information. We may think that farmers maintain in their memory the magnitude of the mistake they made in the previous period and learn by adjusting the difference between actual and expected price in $\mathrm{t}-1$ by a fraction $\lambda$ (Tripathi 2008).

$$
P_{t}=\lambda P_{t-1}+(1-\lambda) P_{t-1}
$$

The first step is substituting Eq. 1 into Eq. 2, and it yields Eq. 4

$$
S_{t}=\eta \delta+(1-\delta) S_{t-1}+\delta \beta P_{t-1}+c Z_{t}+\epsilon_{t}
$$

The second step is to substitute Eq. 3 into Eq. 4. This substitution yields

$$
\begin{aligned}
S_{t}= & \eta \delta+(1-\delta) S_{t-1}+\delta \beta\left[P_{t-1}+(1-\lambda) P_{t-2}+\ldots \ldots \ldots . .\right]+c Z_{t} \\
& +\epsilon_{t}
\end{aligned}
$$

With the advancement of time series analysis, serious methodological issues have been raised on the Nerlovian agricultural supply response model and its estimation techniques. For instance, the Nerlovian model has failed to capture the full dynamics of agricultural supply response (Thiele 2000). The model is also incapable of providing an adequate distinction between short- and long-run elasticities (McKay et al. 1998). Furthermore, the analysis may use non-stationary series, which is a source of spurious regression (Granger and Newbold 1974). To account for these shortcomings of the Nerlovian model, recent studies on supply response have proposed cointegration models. This study also applied a cointegration approach of the error correction model (ECM) to estimate maize supply response. To the best of author's knowledge, only Alemu et al. (2003) have applied this approach in grain supply response estimation in Ethiopia.

After a producer decides on how many hectares of land to allocate for maize production, the maize yield, which is influenced by weather conditions, determines the total maize production. Total maize production or domestic production is 
obtained by multiplying the maize area harvested by the yield level. In the demand block, human consumption, feed and seed consumption, and ending stocks determine the total demand for Ethiopian white maize. Following the law of demand, human and feed consumption are expected to have a downward slope or negative relationship with price. A positive relationship between income, population, and human consumption is expected. Ending stocks comprise the demand for storage and speculation, which indicates a negative relationship between ending stocks and prices.

\section{Model structure}

A single commodity partial equilibrium framework was used to investigate the maize price formation and a likely impact of a bumper harvest and drought shocks on the maize market. The maize market price formation comprises three blocks: supply and demand blocks and model closure (see Fig. 2). A commonly used approach to estimate single equations is ordinary least square (OLS). However, this approach is exposed to the problem of spurious regression in the case of non-stationary variables. Since the estimated parameter values from single equations are used for baseline projections, any misspecifications in the initial stage can contaminate the next stage estimations of baseline projections and model simulation outcomes. In an attempt to overcome this misspecification, the present study estimated the behavioural equations using a combination of OLS (for stationary equations) and an error correction model (ECM) (for non-stationary and cointegrated series). Based on the results of the augmented Dickey-Fuller (ADF) unit root test (Dickey and Fuller 1979), maize area harvested and ending stock equations were estimated using ECM, while maize yield and per capita maize consumption equations were estimated using OLS. Graphical and statistical methods are used to evaluate the adequacy of the model. The model specifications for the behavioural equations are presented in Table 3.

The findings from the maize supply response suggest that farmers respond very little to price in planning their maize acreage (see Table 4). The low price elasticities of supply can be attributed to the subsistence nature of maize farming practices in Ethiopia. Farmers are more concerned for household consumption than market incentives. Maize is mainly produced for household consumption (>75\%). It is only $13 \%$ of maize production that is marketed (Central Statistical Agency (CSA) 2015). The estimated income elasticity was 0.012 , suggesting that a $10 \%$ increase in real per capita GDP would increase per capita maize consumption by $0.12 \%$.

\section{Empirical results}

The results section begins by presenting findings of selected behaviour equations such as maize yield and per capita maize consumption equations and then follows with analysis of the dynamic effects of different production shocks in the developed partial equilibrium model for the Ethiopian white maize market. Here, we are particularly interested in examining the short-run and long-run impact of a bumper harvest and weather-induced shocks on the maize market outlook period from 2017 to 2025 . The introduction of these shocks into the system takes into account the current trends in the maize market in Ethiopia. 
Table 3 Maize model specifications

\begin{tabular}{|c|c|}
\hline Area harvested ${ }^{\mathrm{a}}$ & $\begin{array}{l}H^{m}=\delta_{0}+\delta_{1} P^{m}{ }_{t}+\delta_{2} S^{p}{ }_{t}+\delta_{3} R^{L}+\delta_{t} T_{t}+\varepsilon_{t} \quad 1(a) \\
H^{m}=\theta_{0}+\theta_{1} \Delta P^{m}{ }_{t}+\theta_{2} \Delta P_{t}^{s}+\theta_{3} \Delta R_{t}^{L}-\lambda\left(Y_{t}-a_{0}-a_{1} P^{m}{ }_{t}-a_{2} P_{t}^{s}-a_{3} R_{t}^{L}-a_{4} T_{t}\right)+v_{t} \\
1(b)\end{array}$ \\
\hline Yield & $Y^{m}=R_{t}^{p}+\mathbb{R}^{m}{ }_{t}+S D_{t}^{i}+T_{t}^{L}$ \\
\hline Production & $M^{p}=H^{m} * Y^{m}$ \\
\hline Beginning stocks & $B^{S}=E_{t-1}^{S}$ \\
\hline Supply & $X^{m}=M^{p}+B^{s}+I^{m}$ \\
\hline Ending stocks & $E^{s}=B^{s}+M^{P}-P^{w}+A^{f}$ \\
\hline $\begin{array}{l}\text { Per capita } \\
\text { consumption }\end{array}$ & $C^{m}=S^{w}-P^{w}+G^{d}+S^{05}+S^{11}-T_{t}$ \\
\hline Human consumption & HCons $^{m}=C^{m} *$ Pop \\
\hline Domestic use & DUSE $^{M}=$ FEED $^{m}+$ SEED $^{m}+$ HCons $^{m}$ \\
\hline Demand & $D^{m}=\mathrm{EXPO}^{m}+\mathrm{DUSE}^{M}+E^{s}$ \\
\hline Model closure & $X^{m}=D^{m}$ (market clearing price) \\
\hline
\end{tabular}

Variable names

$H^{m}=$ Planned maize acreage proxied by area harvested in thousand hectares

$P^{m}{ }_{t}=$ Deflated maize producer price (ETB/ton). It is obtained by dividing the nominal maize producer price by $\mathrm{CPI}$ indexed at the 2010 price

$S^{p}{ }_{t}=$ Real producer prices for competing crop (sorghum) (ETB/ton)

$R^{L}{ }_{t}=$ Rainfall amount $(\mathrm{mm})$ prior to sowing period

$T_{t}=$ a time trend variable used as a proxy for technological progress in maize farming

$Y^{m}=$ Maize yield (ton/ha)

$R^{p}=$ Rainfall amount for production season. It includes average rainfall $(\mathrm{mm})$ for the months of June, July, August, and September

$I R^{m}=$ Irrigated maize area (ratio)

$S D^{i}=$ Maize planted with improved seed (ratio)

$T_{t}^{L}=$ Linear trend to capture the overtime effects of maize technological improvement on yield

$M^{P}=$ Maize production

$B^{s}=$ Beginning stock

$E_{t-1}^{s}=$ Lagged ending stock

$X^{m}=$ Total maize supply

$I^{m}=$ Maize import

$P^{w}=$ Real wholesale maize price (ETB/ton)

$A^{f}=$ Wheat food aid quantity (tons)

$C^{m}=$ Per capita maize consumption

$S^{w}=$ Real wholesale sorghum price (ETB/ton)

$G^{d}=$ Real per capita GDP

$S^{05}=$ a shift variable for the period of soaring food prices in the domestic grain market. It takes 1 for the period since 2005 and 0 otherwise

$S^{11}=$ a shift variable for the export ban; 1 for the period since 2011 and 0 otherwise

Pop= Ethiopia population

HCons $^{m}=$ Human maize consumption

DUSE $^{M}=$ Total domestic use of maize

FEED $^{m}=$ Feed use of maize

SEED $^{m}=$ Seed use of maize

$D^{m}=$ Total maize demand

$\mathrm{EXPO}^{m}=$ Maize export

${ }^{a}$ The equation for maize supply response was estimated following the two-stage procedure proposed by Alemu et al. (2003). First, a static long-run equilibrium regression is given by Eq. 1(a), was estimated. Second, a dynamic error correction model as specified in Eq. 1(b) was estimated by including the lagged residual from Eq. 1(a) (of course, the residual from Eq. 1(a) should be stationary). The planned maize acreage is proxied by area harvested. It has been common practice to proxy an acreage decision by area harvested because of the lack of data on area planted (Meyer and Kirsten 2010). Area harvested is preferred to output because farmers have more control on the former than on the latter. This is because agricultural output is subject to fluctuations, which are beyond the control of farmers.

\section{Maize yield}

The maize yield equation was estimated as a function of rainfall, maize area under irrigation, improved seed utilization, and technological improvement over time. The rainfall pattern during land preparation, planting, and maturity stages influences the maize yield. The result of the maize yield equation is presented in Table 5. 
Table 4 Key findings from behavioural equations

\begin{tabular}{ll}
\hline Variables & Elasticity \\
\hline Short-run price elasticities of supply & 0.062 \\
Long-run price elasticities of supply & 0.167 \\
Own elasticity of demand & -0.322 \\
Cross price elasticity of demand & 0.074 \\
Income elasticity of demand & 0.012 \\
Elasticity of maize consumption over time & -0.0071 \\
\hline
\end{tabular}

In the yield equation, the trend variable appeared with the expected positive sign, and it is statistically significant at $5 \%$ significance level. Technological introduction and progress in the maize commodity over the years has, thus, positively contributed to maize yield improvement in Ethiopia. Maize is grown in almost all agrological conditions in Ethiopia, from rainfed highland areas to moisture-stressed lowland areas. Given this wide adaptability, large numbers of households are growing the crop; close to nine million smallholder farmers are growing maize in Ethiopia, more than any other crop being grown in the country. With regard to maize productivity, Ethiopia has registered commendable growth in maize yields (see Fig. 3). The 5-year average maize yield between 2011 and 2015 was estimated at 2.94 tons ha $^{-1}$ (United States Department of Agriculture (USDA) 2015, quoted by Gurmu et al. 2017). Maize yields reached a historic high level of 3.25 tons $\mathrm{ha}^{-1}$ in 2013.

It is important to highlight the main drivers that have contributed to the dramatic change in maize yield and production in Ethiopia. Here, we list three success factors of the maize green revolution in Ethiopia. Firstly, there is relatively good coordination among the various actors involved in maize technology promotion and popularization. The success of maize technology promotion and adoption, including the introduction of hybrid, stress-tolerant and Quality Protein Maize varieties (QPM) in Ethiopia is the result of strong collaborative work by private and public seed enterprises, NGOs (Sasakawa Global 2000), and the national and international research institutes. The introduction of high-yielding and

Table $\mathbf{5}$ Results for maize yield equation

\begin{tabular}{|c|c|c|}
\hline & (1) & (2) \\
\hline Variables & Robust OLS & Elasticity \\
\hline IRRIG & $0.308(28.14)$ & 0.003 \\
\hline SEED & $0.381(1.059)$ & 0.038 \\
\hline LNTREND & $0.460^{* *}(0.191)$ & \\
\hline RAINP & 0.005 (NA) & 1.65 \\
\hline Constant & $-2.4(1.110)$ & \\
\hline Observations & 15 & \\
\hline Adjusted $R^{2}$ & 0.61 & \\
\hline F statistics & $6.49^{* *}$ & \\
\hline
\end{tabular}

Robust standard errors in parentheses; ${ }^{* *} p<0.05,{ }^{*} p<0.1$; no standard errors are reported for the rainfall variable. Because of undesirable coefficient signs, we modified the value of the rainfall variable using a synthetic estimation technique. A synthetic elasticity coefficient value of 1.65 was used to obtain the rainfall coefficient. Given the high dependency of maize production on rainfall, the use of a 1.65 elasticity value is reasonable 


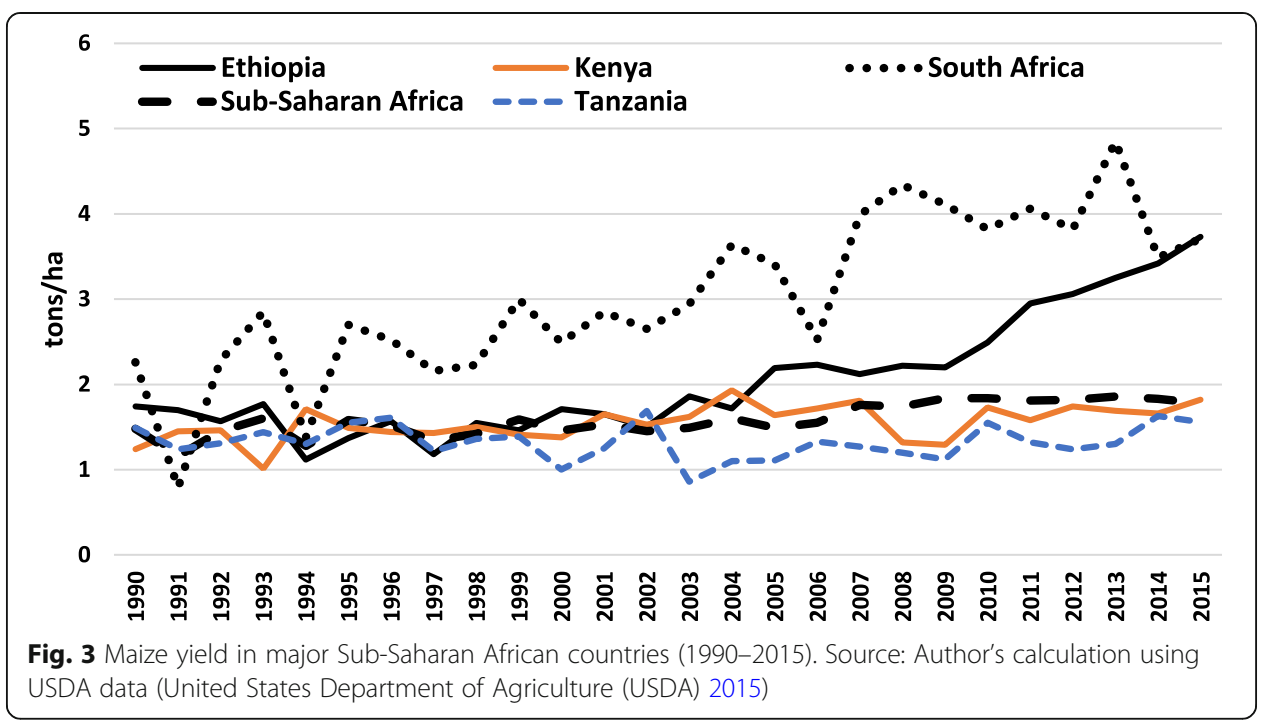

stress-tolerant improved maize varieties has played a key part by replacing the traditional low-yielding maize varieties in Ethiopia. Since 1973, the National Agricultural Research System (NARS) has released a total of 61 maize varieties (Abate et al. 2015). Currently, various institutions are working together to improve maize production and its contribution to food security in Ethiopia. The International Maize and Wheat Improvement Centre (CIMMYT) is the main source of maize germplasm. The Bako Agricultural Research Institute, under the Ethiopian Institute of Agricultural Research (EIAR), has the mandate to coordinate maize research and technology adaptation and generation in Ethiopia. Regional and federal seed enterprises multiply basic and certified maize seed for wider dissemination. Moreover, private sector participants, such as Pioneer Hybrid, are also involved in hybrid maize seed production and marketing to farmers. The Ministry of Agriculture (MoA) and EIAR have the mandate to popularize and demonstrate newly released maize varieties and empower farmers through subsequent training sessions. The recently established Agricultural Transformation Agency (ATA) is also working on maize value chain development in Ethiopia

Secondly, the focus given by the Ethiopian government to modernizing the agricultural extension system and improving its accessibility to farmers needs great appreciation. The introduction of new technologies alone does not guarantee yield improvement, unless accompanied by a modern extension system. The agricultural extension approach of Ethiopia could serve as a role model for Africa. In every district, the government has assigned three professional agricultural extension workers to help farmers with crop technology, livestock husbandry, and sustainable land management practices. Since 2000, Ethiopia has trained 63,000 extension agents. This has improved the extension agent-to-farmer ratio. Ethiopia's extension agent-to-farmer ratio is estimated at 1:476, compared to 1:1000 for Kenya, 1:1603 for Malawi, and 1:2500 for Tanzania (Kassie et al. 2015). This achievement is believed to improve the uptake of modern farmenhancing technologies. Thirdly, the even distribution of rainfall over the last two 
Table 6 Results for per capita maize consumption

\begin{tabular}{llc}
\hline & $(1)$ & $(2)$ \\
Variables & Robust OLS & Elasticity \\
\hline RMPRICE & $-0.0045(0.008)$ & -0.322 \\
RPCGDP & $0.117(0.167)$ & 0.012 \\
RSORGPRICE & $0.007(0.008)$ & 0.074 \\
SHIFT05 & $11.12^{*}(5.592)$ & \\
SHIFT2011 & $14.65^{*}$ & -0.0071 \\
TREND & $-2.894(3.867)$ & \\
Constant & $12.72(22.567)$ & \\
Observations & 15 & \\
Adjusted $R^{2}$ & 0.64 & \\
$F$ statistics & $5.086^{* *}$ & \\
\hline Robust standard errors in parentheses; ${ }^{* *} p<0.05, * 0<0.1$
\end{tabular}

decades has played a favourable role in increasing maize productivity in Ethiopia (see Table 2).

\section{Per capita maize consumption}

The findings for the drivers of per capita white maize consumption in Ethiopia are illustrated in Table 6. Per capita maize consumption is modelled as a function of own price, price of substitutable crop (i.e. sorghum), real per capita GDP, and two shift variables capturing the soaring food price phenomena and changes in the policy environment from free trade to export ban. A trend variable is also incorporated to examine the changing trend in the consumption habits of maize consumers over time.

All the estimated variables in the per capita white maize consumption have the expected signs. Economic theory has taught us that basic goods tend to have an inelastic demand. Maize is a basic commodity in Ethiopia and, therefore, as the maize price increases, consumers do not immediately alter their usual consumption of maize. Instead, they decrease their maize consumption moderately. This is evidenced by the negative elasticity coefficient of the real wholesale maize price, which is 0.322 , implying that a $10 \%$ increase in real wholesale maize price would lead to a decrease in per capita maize consumption by $3.22 \%$. The estimated income elasticity is 0.012 , suggesting that a $10 \%$ increase in real per capita GDP would increase maize per capita consumption by $0.12 \%$.

The trend variable appeared with a negative sign, indicating the decline in the share of maize in the consumption basket of consumers, over time. This could be attributed to the increase in urbanization. It has been well documented that owing to urbanization, people tend to move away from the consumption of root crops and coarse grains to wheat and rice. However, the effect of the trend variable is small, which is an indication that the composition of food baskets in Ethiopia is fairly constant. The elasticity for the trend variable was -0.0071 , which implies that in each year, per capita maize consumption decreases by 
$0.071 \%$. The elasticity is small because the majority (85\%) of the Ethiopian population reside in rural areas. In the rural areas of Ethiopia, maize is the main staple food crop. Hence, the decreasing trend being captured at the national level is because of changes in the diets of urban consumers. In urban areas, wheat and teff crops are the most preferred crop for consumption (Worku et al. 2015).

The real wholesale sorghum price incorporates the effect of substitutes in maize consumption in Ethiopia. The sorghum price has a positive effect on maize consumption: if the price of a substitute crop increases, maize consumption will increase. However, maize consumption is inelastic to the sorghum price. A $10 \%$ increase in the sorghum price would lead to an increase in per capita maize consumption by $0.74 \%$. Both shift variables that take into account the effect of soaring food price phenomena and the export ban on maize consumption were positive and significant at $10 \%$ significance level. Maize is one of the food crops that have experienced soaring food prices in the domestic grain market. The positive and significant relationship of maize per capita consumption to high market price environment is not a surprise. As stated earlier, maize is mainly produced for home consumption. Therefore, the decision to produce maize is mainly influenced by subsistence requirements, rather than by market price dynamics. One possible reason for the positive relationship between maize consumption and price hikes could be that farmers may increase the marketing of high price commodities. An increase in the marketability of other cereals could increase the use of maize for household consumption. Maize consumption has shown an upward trend since 2005. On average, maize per capita consumption increased by $46 \%$ from $31.8 \mathrm{~kg}$ per person during $2001-2004$ to $46.57 \mathrm{~kg}$ per person during 2005-2015.

The shift variable (SHIFT2011), capturing the effect of an export ban on maize consumption, is also significant and positive. This result is consistent with a prior expectation and economic theory that an export ban in the face of high domestic maize production would lower maize price in the domestic market. As a result, consumers would enjoy low prices through increasing their maize consumption. However, this assertion would work only if the export of maize became profitable. Removing an export ban has no effect if exports are not profitable.

Impact of a bumper harvest

As outlined above, Ethiopia is one of the few countries in Sub-Saharan Africa (SSA) that has attained $>3$ tons per hectare in maize yields. This is regarded as a big achievement for a smallholder-dominated maize producer country such as Ethiopia. Ethiopia exceeded 3 tons per hectare in the 2012 and 2013 production seasons (see Fig. 3). The average maize yield during these two periods was 3.2 tons $\mathrm{ha}^{-1}$. This figure represents a $50 \%$ increase, compared with the preceding eleven years (2001-2011) which had a maize yield average of 2.10 tons $\mathrm{ha}^{-1}$. The success in maize yield improvement emanates from a better breeding strategy that considers the heterogeneous typology of maize production in Ethiopia. The current maize yield is 2.9 tons $\mathrm{ha}^{-1}$, and there is still much scope for improving the current maize yield through the intensification of chemical fertilizer utilization, 
conservation farming, mechanization, and investment in irrigation infrastructure. Therefore, it is reasonable to believe that the country can replicate the success in maize productivity with the expected improvement in government investment in the above-mentioned infrastructural facilities. To this end, we introduced a $20 \%$ shock in maize yield into the partial equilibrium maize model for Ethiopia. The shock was introduced in the 2017 baseline period.

The dynamic responses of the maize sub-sector to a bumper harvest are summarized in Table 7. The impact of the yield simulation is more pronounced and persistent for maize ending stocks and the nominal maize price. As compared with the baseline, a $20 \%$ increase in the maize yield could reduce the maize price substantially, by $81 \%$. There have been previous experiences of maize price collapse of such magnitude. In Ethiopia, maize prices collapsed considerably whenever there are bumper harvests. This was the case in 1999 and 2002 (RATES 2003). For instance, following the 2 years consecutive bumper harvests, maize prices dropped by about $80 \%$ in 2002. As a result, the Ethiopian government procured 18,000 MT of maize, of which 11,000 MT was exported. Furthermore, a 20\% positive yield shock would

Table $\mathbf{7}$ Impact of a bumper harvest on the maize market

\begin{tabular}{|c|c|c|c|c|c|c|c|c|c|}
\hline Affected components & 2017 & 2018 & 2019 & 2020 & 2021 & 2022 & 2023 & 2024 & 2025 \\
\hline Maize yield & \multicolumn{9}{|l|}{ Tons/ha } \\
\hline Baseline & 2.86 & 2.91 & 2.89 & 2.88 & 2.92 & 2.93 & 2.96 & 2.94 & 3.00 \\
\hline Scenario & 3.43 & 2.91 & 2.89 & 2.88 & 2.92 & 2.93 & 2.96 & 2.94 & 3.00 \\
\hline Absolute change & 0.57 & 0.0 & 0.0 & 0.0 & 0.0 & 0.0 & 0.0 & 0.0 & 0.0 \\
\hline$\%$ change & $20 \%$ & $0 \%$ & $0 \%$ & $0 \%$ & $0 \%$ & $0 \%$ & $0 \%$ & $0 \%$ & $0 \%$ \\
\hline Maize production & \multicolumn{9}{|c|}{ Thousand tons } \\
\hline Baseline & 6890 & 7193 & 7324 & 7498 & 7759 & 7972 & 8242 & 8374 & 8755 \\
\hline Scenario & 8262 & 7193 & 7324 & 7498 & 7759 & 7972 & 8242 & 8374 & 8755 \\
\hline Absolute change & 1373 & 0.0 & 0.0 & 0.0 & 0.0 & 0.0 & 0.0 & 0.0 & 0.0 \\
\hline$\%$ change & $20 \%$ & $0 \%$ & $0 \%$ & $0 \%$ & $0 \%$ & $0 \%$ & $0 \%$ & $0 \%$ & $0 \%$ \\
\hline Domestic maize use & \multicolumn{9}{|c|}{ Thousand tons } \\
\hline Baseline & 6858 & 7126 & 7277 & 7455 & 7692 & 7909 & 8165 & 8325 & 8661 \\
\hline Scenario & 7849 & 7337 & 7372 & 7498 & 7711 & 7918 & 8169 & 8326 & 8662 \\
\hline Absolute change & 991 & 211 & 95 & 43 & 19 & 9 & 4 & 1 & 0 \\
\hline$\%$ change & $14 \%$ & $3 \%$ & $1 \%$ & $1 \%$ & $0 \%$ & $0 \%$ & $0 \%$ & $0 \%$ & $0 \%$ \\
\hline Ending stocks & \multicolumn{9}{|c|}{ Thousand tons } \\
\hline Baseline & 441 & 509 & 556 & 599 & 666 & 728 & 805 & 854 & 948 \\
\hline Scenario & 823 & 680 & 632 & 632 & 681 & 734 & 808 & 855 & 949 \\
\hline Absolute change & 382 & 171 & 76 & 34 & 15 & 6 & 3 & 1 & 1 \\
\hline$\%$ change & $87 \%$ & $34 \%$ & $14 \%$ & $6 \%$ & $2 \%$ & $1 \%$ & $0 \%$ & $0 \%$ & $0 \%$ \\
\hline Nominal wholesale maize price & \multicolumn{9}{|l|}{ ETB/ton } \\
\hline Baseline & 5733 & 5599 & 5845 & 5989 & 5717 & 5465 & 4855 & 4742 & 3759 \\
\hline Scenario & 1061 & 4545 & 5347 & 5756 & 5609 & 5416 & 4833 & 4732 & 3755 \\
\hline Absolute change & -4672 & -1054 & -498 & -233 & -108 & -49 & -22 & -10 & -4 \\
\hline$\%$ change & $-81 \%$ & $-19 \%$ & $-9 \%$ & $-4 \%$ & $-2 \%$ & $-1 \%$ & $0 \%$ & $0 \%$ & $0 \%$ \\
\hline
\end{tabular}

Source: Model outcome 
increase maize ending stocks by $87 \%$ in the short run, and the effect will also continue in the long run. A positive change in maize yield would lead to an increase in ending stocks by $34 \%, 14 \%, 6 \%$, and $2 \%$ in 2018, 2019, 2020, and 2021, respectively. A moderate impact is noticed on domestic maize use; a $20 \%$ increase in maize yield could increase domestic maize use by $14 \%$.

The maize area harvested has remained unaffected by the $20 \%$ positive increase in maize yield. The non-responsiveness of maize area harvested to the yield shock raises some doubt on the estimation method. As illustrated above, maize area is estimated differently from the rest of the behavioural equations. We estimated the maize supply response using the ECM in order to account for the spurious regression problem. We then plugged the short-run elasticity values into the partial equilibrium model. This may have created disconnection between the maize area harvested and the price model. ${ }^{4}$

\section{Impact of a drought}

Staple food crops, such as maize, are prone to weather-related shocks in Ethiopia. In 2015, maize production and consumption subsided owing to the effect of drought (El Nino). Drought reduced maize production by 23\% in 2015 (United States Department of Agriculture (USDA) 2017). This is not surprising because the majority of maize is produced in a rainfed farming system. Only $2 \%$ of maize production is grown under irrigation (CSA, 2015). Therefore, understanding the possible impact of rainfall shocks on the maize market is crucial for designing an early warning system and a price stabilization policy. The analysis would also help food aid agencies to accurately project consumption shortfalls and food aid need.

Table 8 presents the findings from the simulation analysis. The shocks were invoked into the system in 2017. From the analysis, it can be seen that the components most affected by drought are ending stocks and maize price. The effects are also more persistent in these two components. A $10 \%$ combined decrease in rainfall amount during the planting and the main season maize production months in the major maize-producing areas would decrease maize ending stocks by $64 \%$ in the short run. The effect also continues in the long run. On the other hand, the effect of a drought would increase maize prices by $61 \%$. In the long run, a $10 \%$ combined decrease in rainfall amount during the planting and the main season maize production months would lead to an increase in maize prices by $14 \%, 6 \%$, and $3 \%$ during 2018,2019 , and 2020 , respectively.

\section{Should maize be exported?}

An interesting follow-up question would be whether shocks (a bumper harvest) in the maize industry would necessitate a temporary lift of the export ban on maize. From a policy perspective, addressing this question is important to provide policy alternatives for the Ethiopian government as to whether to lift the export ban temporarily in case of a good harvest season and to allow private traders to export

${ }^{4}$ The maize supply response equation was estimated using an Error correction model to overcome spurious regression problems. Hence, we used the first differenced maize price variable as opposed to lagged prices. This appears to have caused unresolved issues with the scenario analysis. 
Table 8 Impact of a drought

\begin{tabular}{|c|c|c|c|c|c|c|c|c|c|}
\hline Affected components & 2017 & 2018 & 2019 & 2020 & 2021 & 2022 & 2023 & 2024 & 2025 \\
\hline Area harvested & \multicolumn{9}{|c|}{ Thousand hectare } \\
\hline Baseline & 2408 & 2472 & 2536 & 2602 & 2661 & 2725 & 2789 & 2850 & 2922 \\
\hline Scenario & 2366 & 2472 & 2536 & 2602 & 2661 & 2725 & 2789 & 2850 & 2922 \\
\hline Absolute change & -42 & 0.0 & 0.0 & 0.0 & 0.0 & 0.0 & 0.0 & 0.0 & 0.0 \\
\hline$\%$ change & $-2 \%$ & $0 \%$ & $0 \%$ & $0 \%$ & $0 \%$ & $0 \%$ & $0 \%$ & $0 \%$ & $0 \%$ \\
\hline Maize yield & \multicolumn{9}{|c|}{ Tons/Ha } \\
\hline Baseline & 2.86 & 2.91 & 2.89 & 2.88 & 2.92 & 2.93 & 2.96 & 2.94 & 3.00 \\
\hline Scenario & 2.48 & 2.91 & 2.89 & 2.88 & 2.92 & 2.93 & 2.96 & 2.94 & 3.00 \\
\hline Absolute change & -0.38 & 0.0 & 0.0 & 0.0 & 0.0 & 0.0 & 0.0 & 0.0 & 0.0 \\
\hline$\%$ change & $-13 \%$ & $0 \%$ & $0 \%$ & $0 \%$ & $0 \%$ & $0 \%$ & $0 \%$ & $0 \%$ & $0 \%$ \\
\hline Maize production & \multicolumn{9}{|c|}{ Thousand tons } \\
\hline Baseline & 6890 & 7193 & 7324 & 7498 & 7759 & 7972 & 8242 & 8374 & 8755 \\
\hline Scenario & 5871 & 7193 & 7324 & 7498 & 7759 & 7972 & 8242 & 8374 & 8755 \\
\hline Absolute change & -1019 & 0.0 & 0.0 & 0.0 & 0.0 & 0.0 & 0.0 & 0.0 & 0.0 \\
\hline$\%$ change & $-15 \%$ & $0 \%$ & $0 \%$ & $0 \%$ & $0 \%$ & $0 \%$ & $0 \%$ & $0 \%$ & $0 \%$ \\
\hline Domestic maize use & \multicolumn{9}{|c|}{ Thousand tons } \\
\hline Baseline & 6858 & 7126 & 7277 & 7455 & 7692 & 7909 & 8165 & 8325 & 8661 \\
\hline Scenario & 6123 & 6969 & 7206 & 7424 & 7678 & 7903 & 8162 & 8324 & 8660 \\
\hline Absolute change & -735 & -157 & -70 & -31 & -14 & -6 & -3 & -1 & -1 \\
\hline$\%$ change & $-11 \%$ & $-2 \%$ & $-1 \%$ & $0 \%$ & $0 \%$ & $0 \%$ & $0 \%$ & $0 \%$ & $0 \%$ \\
\hline Ending stocks & \multicolumn{9}{|c|}{ Thousand tons } \\
\hline Baseline & 441 & 509 & 556 & 599 & 666 & 728 & 805 & 854 & 948 \\
\hline Scenario & 157 & 382 & 500 & 574 & 655 & 723 & 803 & 853 & 948 \\
\hline Absolute change & -284 & -127 & -56 & -25 & -11 & -5 & -2 & -1 & 0 \\
\hline$\%$ change & $-64 \%$ & $-25 \%$ & $-10 \%$ & $-4 \%$ & $-2 \%$ & $-1 \%$ & $0 \%$ & $0 \%$ & $0 \%$ \\
\hline Nominal wholesale maize price & \multicolumn{9}{|l|}{ ETB/ton } \\
\hline Baseline & 5733 & 5599 & 5845 & 5989 & 5717 & 5465 & 4855 & 4742 & 3759 \\
\hline Scenario & 9201 & 6382 & 6215 & 6162 & 5797 & 5502 & 4872 & 4750 & 3762 \\
\hline Absolute change & 3469 & 783 & 370 & 173 & 80 & 37 & 17 & 8 & 3 \\
\hline$\%$ change & $61 \%$ & $14 \%$ & $6 \%$ & $3 \%$ & $1 \%$ & $1 \%$ & $0 \%$ & $0 \%$ & $0 \%$ \\
\hline
\end{tabular}

Source: Model outcome

maize. This can be done by comparing the domestic maize prices with the IPP and EPP under different domestic maize harvest scenarios. ${ }^{5}$ It should be noted that this comparison is made by assuming the maize export ban will remain unchanged during the simulation period. In practice, it is unlikely to expect a country not to import and export a commodity in times of drought and bumper harvests. However, this analysis at least allow us to examine the dynamic impact of production shocks

\footnotetext{
${ }^{5}$ Several assumptions were made to conduct the maize parity price analysis under different domestic maize harvest scenarios. Some of the assumptions include port handling, loading/unloading, and inland transport costs from Diibouti port to the central Addis Ababa wholesale maize market were assumed to remain constant during the simulation period of 2017. Apart from the 5\% import tariff rate, other policy effects were not incorporated into the calculations of the EPP and IPP analysis. Furthermore, the net trade is assumed to be zero for the periods from 2016 to 2025.
} 




Fig. 4 White maize export parity price analysis with scenario 1, 2005-2017. Note: Export parity analysis is calculated using the US No 2, yellow maize, Gulf of Mexico. Source: Author's calculation

on the profitability of maize import and export decisions without incorporating a trade equation into the partial equilibrium maize model for Ethiopia.

\section{Scenario 1: A bumper harvest}

As we noted in the yield simulation analysis, a $20 \%$ increase in the maize yield would decrease the maize price by $81 \%$. Because of an increase in the maize yield, the domestic maize price would become lower than the export parity price for the shock period. In the short run (within the year), the domestic maize price declines 70\% (110 USD/t) below the lower threshold EPP. This makes maize exports profitable and has resulted in a trade regime shift from autarky to export parity trade regime for the Ethiopian white maize market (Fig. 4). In this scenario, therefore, lifting the export ban on maize would be an advisable policy option for curbing further reductions in the maize price. Removal of the export ban would increase the domestic maize prices above what the prices would be under the ban. This would, in turn, encourage domestic maize producers and private traders who operate in the maize market. Complete results are illustrated in Table 11 in Appendix.

\section{Scenario 2: A drought season}

As stated above, the effect of a drought would increase the maize price by $61 \%$ in the short run. This has resulted in the domestic wholesale maize price moving over the upper threshold IPP by 46\% (126 USD/t). As a result, maize imports would become profitable (Fig. 5).

\section{Potential exportable markets}

Ethiopia could possibly export maize to the deficit South Sudan and Kenyan maize markets. South Sudan has increased maize import because of a decrease in sorghum imports from North Sudan. Maize imports increased from 176 thousand 


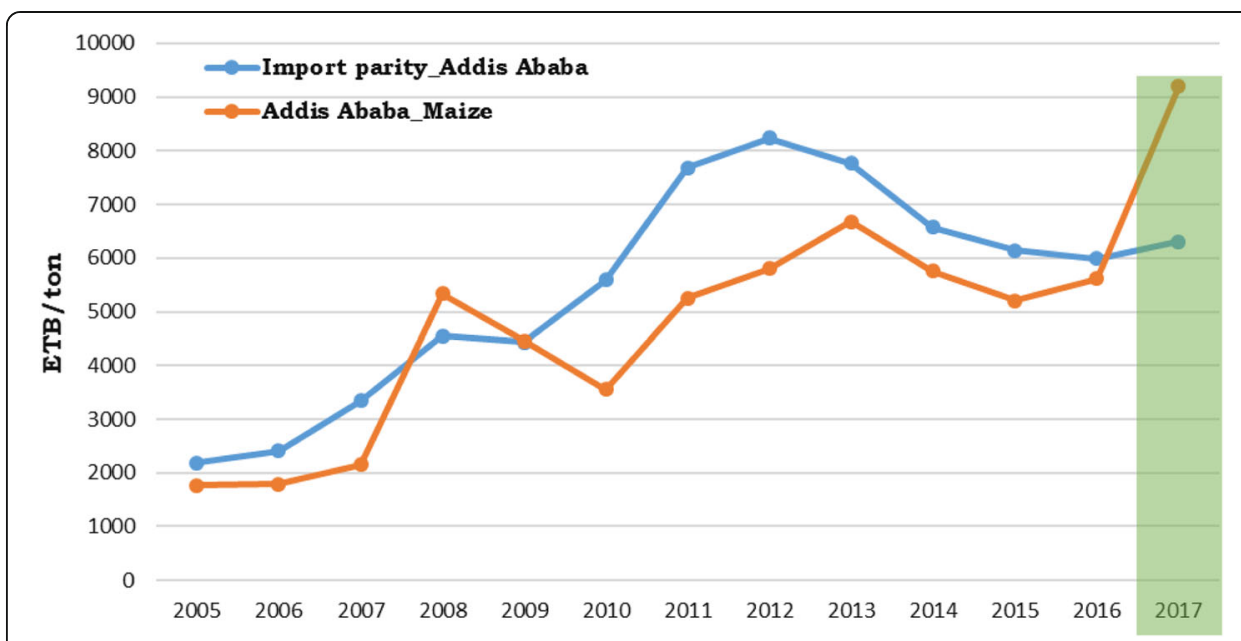

Fig. 5 Import parity price analysis for white maize with scenario 2, 2005-2017. Note: Import parity analysis is calculated using the US No 2, yellow maize, Gulf of Mexico. Source: Author's calculation

tons in 2009 to 583 thousand tons in 2013. Moreover, the domestic demand for maize has increased; and per capita maize consumption is higher than per capita sorghum consumption in Juba (Dorosh et al. 2016). The other export destination market could be the Kenyan maize market, through the Moyale border. In this section, we test long-run relationships between Addis Ababa maize market prices with South Sudan and Kenya regional maize markets using the Johansen and Juselius (1990) cointegration approach. The results are given in Table 9.

Having found that all maize price series are integrated of order one I (1), we proceed by estimating the presence of a long-run relationship using Trace and Maximum-eigenvalue test statistics (Table 10). Based on the trace test statistics, we found no cointegration between Addis Ababa and Kenya's maize markets at Nairobi and Mombasa. The absence of a long-run relationship could be attributed to high transport costs linking Ethiopia with Kenya. The average wholesale monthly

Table 9 Johansen cointegration tests between regional maize markets

\begin{tabular}{llllll}
\hline Market pairs & Sample period & $\begin{array}{l}\text { Lag } \\
\text { length }\end{array}$ & Hypothesis & $\lambda_{\text {trace }}$ & $\lambda_{\max }$ \\
\hline Nairobi-Addis Ababa & 2006 M01-2017 & 1 & $r=0$ & $12.26(12.32)$ & $12.25^{* *}$ \\
& M01 & & & & $(11.22)$ \\
& & & $r \leq 1$ & $0.01(4.13)$ & $0.01(4.13)$ \\
Mombasa-Addis Ababa & 2006 M01-2017 & 1 & $r=0$ & $10.37(12.32)$ & $10.31(11.22)$ \\
& M01 & & $r \leq 1$ & $0.065(4.13)$ & $0.065(4.13)$ \\
Juba-Addis Ababa & 2011 M08-2017 & 1 & $r=0$ & $15.71^{* *}$ & $15.66^{* * *}$ \\
& M01 & & & $(12.32)$ & $(11.22)$ \\
& & & $r \leq 1$ & $0.052(4.13)$ & $0.052(4.129)$ \\
Juba-Addis Ababa with shift & 2011 M08-2017 & 2 & $r=0$ & $22.15^{* * *}$ & $22.03^{* * *}$ \\
dummy & M01 & & & $(12.32)$ & $(11.22)$ \\
& & & $r \leq 1$ & $1.53(4.13)$ & $1.53(4.13)$ \\
\hline
\end{tabular}

${ }_{* * *}^{* * *}$ significance levels at $1 \%$ and $5 \% ; r$ is the number of cointegrating vectors; lag length is selected using Akaike Information Criteria (AIC); critical values in parenthesis; all maize prices series are converted to logarithms; South Sudan received independency in July 2011. Therefore, Juba's maize price is from August 2011 onward 
Table 10 Vector error correction model results for Juba and Addis Ababa market pairs

\begin{tabular}{ll}
\hline Coefficients & Cointegrating vector and adjustment coefficient \\
\hline$P_{t-1}^{E T H}$ & $1.139^{* *}$ \\
$E C T_{t-1}$ & $-0.236^{*}$ \\
Half-life & 2.57 \\
Short-run parameters & \\
$\Delta P_{t-1}^{\text {UUBA }}$ & -0.209 \\
$\Delta P_{t-2}^{\text {UUBA }}$ & 0.073 \\
$\Delta P_{t-1}^{E T H}$ & -0.618 \\
$\Delta P_{t-2}^{E T H}$ & -1.007 \\
Shift13 & $0.076^{*}$ \\
Model specification tests & \\
LM (3) test & 0.71 \\
Adj. portmanteau test & 0.39 \\
Normality test & $438^{* * *}$ \\
MARCH-LM test & $54.77^{* *}$ \\
ARCH LM test & 0.36 \\
\hline
\end{tabular}

Half-life is computed as $h=\left[\ln (0.5) /(\ln (1+a)]\right.$, where $a$ is the error correction term $\left(E C T_{t-1}\right)$ and interpreted in months; adj. portmanteau test denotes adjusted portmanteau test which has more powerful small sample properties than the standard portmanteau test (see Lütkepohl and Krätzig 2004, 127); MARCH-LM test denotes multivariate ARCH test; ****** reject the null hypothesis at 1 and 5\% significance levels, respectively

white maize price from January 2006 to January 2017 in Addis Ababa was 256 USD/ton, while it was $314 \mathrm{USD} /$ ton in the Nairobi and $315 \mathrm{USD} /$ ton in the Mombasa maize markets. According to Rashid et al. (2010), even a price difference of $100 \mathrm{USD} /$ ton would not trigger profitable maize exports because of the high transport costs on the routes from Addis Ababa to Nairobi. The section between Awassa and Moyale in Ethiopia, and the section between Moyale and Marsabit, are in particularly bad condition. In addition, there are occasional security problems between Moyale and Marsabit. The poor road infrastructure and security risks may raise transportation costs, which reduce the export parity price in Ethiopia (Minot 2013). However, in the simulation analysis, because of a $20 \%$ positive yield shock, the Addis Ababa wholesale maize price could decrease by 110 USD/ton below the export parity price. This may be enough to stimulate profitable maize exports to Kenya.

South Sudan has experienced a renewed civil war since December 2013. Although a peace agreement was signed in 2015, the war continues. To account for the impact of the renewed civil war in the cointegration rank, a shift dummy variable was incorporated. The results for the cointegration rank test, with and without a structural shift variable, are reported in Table 9. In both cases, the trace and maximum eigenvalue test statistics rejected the null of zero cointegrating vector $(r=0)$ in favour of one cointegrating vector. Thus, cointegration between the Juba and Addis Ababa maize markets presents in both cases. The only difference is that the value of the test statics increase when we take into account a structural break for the renewed conflict. This makes sense because, in the presence of war, transaction costs are likely to increase and thus reduce the possibility of cointegration. 
Evidence of cointegration between the Addis Ababa and Juba maize markets was not expected because of two reasons. Firstly, the cross-border trade between Ethiopia with South Sudan faces high risks and transportation costs, making maize export less profitable for traders. However, our results indicated that the occurrence of war does not fully impede trade and price signal flows across spatial maize markets. These results are in line with the findings of Dorosh et al. (2016). Secondly, the maize export ban is expected to impede trade between regional maize markets. One possible explanation for the presence of cointegration could be that, because of the proximity of South Sudan to Ethiopia, trade flows might not be the only price adjustment mechanism. Instead, these two regional maize market prices may follow each other through information flows, which might bring prices back to the equilibrium state in the long run. In recent years, there are a large body of literature on spatial market integration that suggest the importance of information flows as one means of mechanisms that brings markets into equilibrium state. Information flows, which are one of the overlooked and underappreciated elements of market equilibrium, may contribute to spatial market integration in the absence of physical trade flows between markets (Stephens et al. 2008). However, the speed of price adjustment to the previous year disequilibrium is low. As reported in Table 10, it takes more than 2 months for the Juba maize market to correct $50 \%$ of Addis Ababa maize price shocks.

\section{Conclusion and policy recommendations}

In this article, we examine the dynamic effects of weather-induced and bumper harvest shocks on the developed partial equilibrium model for the Ethiopian white maize market. From the yield simulation analysis, we found that a $20 \%$ increase in maize yield would result in an increase in maize production by $20 \%$. The impact of the yield simulation was more pronounced and persistent on maize ending stocks and the maize price. As compared with the baseline, a 20\% increase in the maize yield would reduce the maize price by $81 \%$. On the other hand, the occurrence of a drought would increase the maize price by $61 \%$ in the short run.

We have also investigated the possible impact of such shocks on the profitability of maize import and export decisions. We demonstrated that, owing to a $20 \%$ increase in the maize yield, the domestic maize price would become lower than the export parity price for the shock period. In the short run (within the year), the domestic maize price would fall $70 \%$ below the lower threshold EPP. This makes maize exports profitable and shifts the trade regime from autarky to an export parity regime. In this scenario, therefore, the lifting of the export ban on maize would be an advisable policy option for cushioning further reductions in the maize price. Therefore, if a maize harvest is expected to be above average, it is advisable for the government to lift the export ban on maize. Removing the export ban on maize would set a limit on the domestic price of maize equal to the export parity price. This would keep farmers from being discouraged by low maize prices during good harvest seasons. On the other hand, the effect of drought would result in the domestic wholesale maize price moving over the 
upper threshold IPP by $46 \%$ (126 USD/t). As a result, maize import would become profitable.

The frequent and unpredictable lifting and re-imposition of export bans since 2006 have created uncertainty in the maize market in Ethiopia (see Food and Agriculture Policy Decision Analysis Tool (FAPDA) 2017). Thus, intensive dialogue between the government and the private sector about trade policy decision-making would restore trust in the grain market environment. Furthermore, the introduction and re-introduction of export restrictions should be made predictable and transparent. Such a move from discretionary to predictable state interventions would boost the confidence of the private sector in maize marketing.

The Ethiopian government should revisit the export ban policy. In our study, we have shown that, given the current maize price trends, it is not relevant to impose the ban since maize exports are unprofitable. At the current market price, the domestic maize price is wandering between the border prices and it is unprofitable to export maize. Therefore, lifting the export ban, even during normal harvest seasons, would not do any harm to the domestic maize price. As a policy alternative, we recommend that the government should lift the maize export ban, depending on the magnitude of production shocks such as a bumper harvest.

The findings from the regional maize market integration analysis have shown that, despite the renewed conflict in South Sudan, the Addis Ababa maize market is cointegrated with Juba's maize market. Better market integration with regional maize deficit markets would reduce maize price instability in times of bumper harvests in Ethiopia. However, the cross-border trade between Ethiopia with regional deficit markets, such as those in South Sudan and Kenya, faces high risks and transportation costs, making maize exports less profitable for traders. Therefore, there is a need to invest in the road transportation infrastructure that links Ethiopia with potential maize export destinations such as markets in Kenya and South Sudan. Since maize is traded mainly through cross-border trade, better infrastructural development would enable Ethiopia to become a consistent maize exporter to neighbouring eastern African countries. This would improve the competitiveness of maize exports. Public investment in roads can reduce transportation costs and increase maize export parity prices, making maize exports more profitable to private traders.

Estimating behavioural equations using the ECM to account for non-stationarity problems likely comes at the cost of missing the true reflection of the impact of production shocks on the different components of the maize market in Ethiopia. In this study, a price linkage equation could not be introduced because of the excessive zero trade values in the historical data that made it impossible to estimate a trade equation. Henceforth, to ensure that market realities can be captured, future studies could adopt alternative model closures through following synthetic estimation techniques where elasticities are imposed. It will remain a challenge for any large simulation system like a partial equilibrium model to weigh up statistical robustness with a system that captures more of the salient market realities. It is therefore recommended that future studies take a fine balanced approach of imposing statistical robustness as far as data allows, but also ensuring that the modelling system is able to handle market realities. 


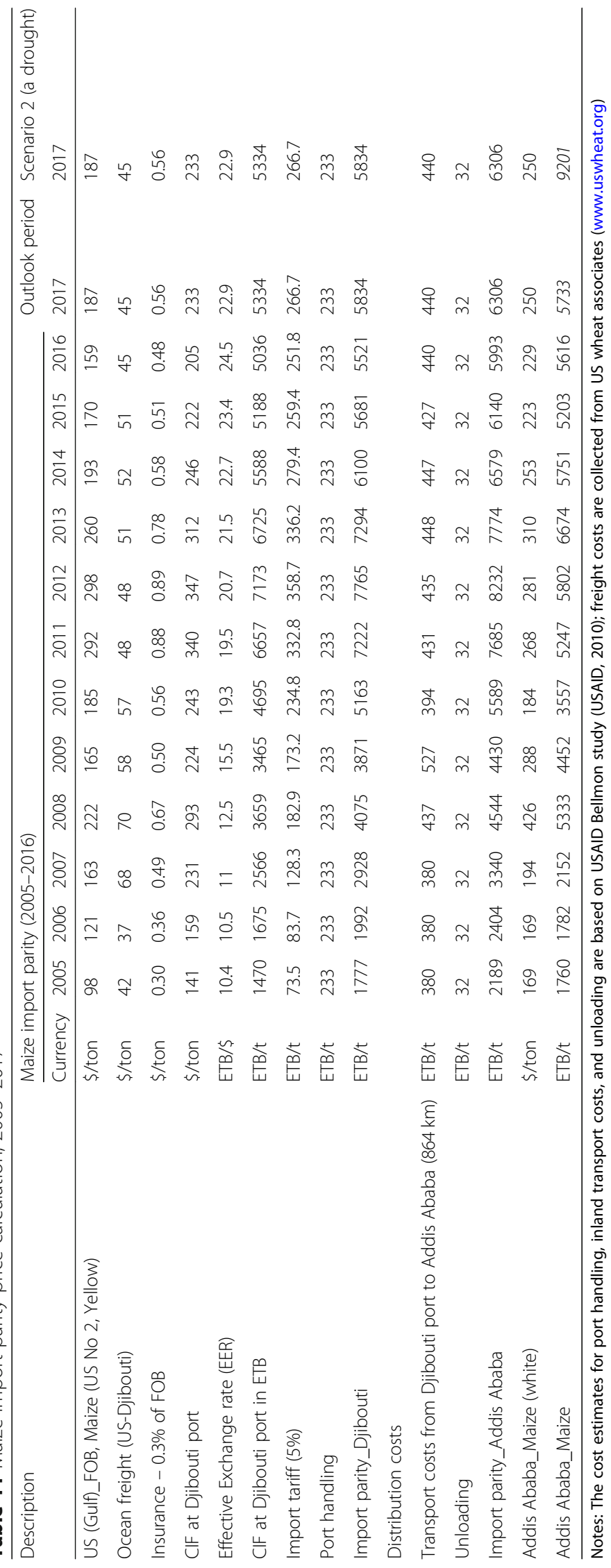


Acknowledgements

Not applicable.

\section{Authors' contributions}

MY conceived of the study, participated in the designing of the data collection instruments, collected the data, and performed the statistical analysis. FM and RH provided comments on the draft manuscript. All authors read and approved the final manuscript.

\section{Funding}

The authors gratefully acknowledge the financial support from the Bureau for Food and Agricultural Policy (BFAP).

\section{Availability of data and materials}

The datasets used for the study are available from the corresponding author upon request.

\section{Competing interests}

The authors declare that they have no competing interests.

\section{Author details}

'Department of Agricultural Economics, Extension and Rural Development, University of Pretoria, Pretoria, South Africa.

${ }^{2}$ Bureau for Food and Agricultural Policy (BFAP), University of Pretoria, Pretoria, South Africa. ${ }^{3}$ Centre for Environmental Economics and Policy Analysis (CEEPA), University of Pretoria, Pretoria, South Africa.

Received: 23 February 2019 Accepted: 16 January 2020

Published online: 18 February 2020

\section{References}

Abate T, Bekele S, Abebe M, Dagne W, Yilma K, Kindie T, Menale K, Gezahegn B, Berhanu T, Tolera K (2015) Factors that transformed maize productivity in Ethiopia. F Sec 7:965-981

Alemu ZG, Oosthuizen K, Schalkwyk HV (2003) Grain-supply response in Ethiopia: an error-correction approach. Agrekon 42: 389-404

Central Statistical Agency (CSA) (2015) Agricultural Sample Survey 2014/2015. Vol I. Report on area and production of major crops (private peasant holdings, Meher season)

Chapoto A, Jayne T (2009) The impacts of trade barriers and market interventions on maize price predictability: evidence from eastern and southern Africa. Michigan State University international development draft working paper 102

Demeke M, Opazo CM, Doroudian A (2014) Staple food prices in sub-Saharan Africa in the context of a crisis: challenges and policy options, Scientific Paper 7B, ULYSSES project, EU 7th Framework Programme, Project 312182 KBBE.2012.1.4-05, http://www.fp7-ulysses.eu

Demeke M, Pangrazio G, Maetz M (2009) Country responses to the food crisis: nature and preliminary implications of the policies pursued. Initiative on soaring food prices. FAO, Rome

Dercon S (2004) Growth and shocks: evidence from rural Ethiopia. J Dev Econ 74:309-329

Dercon S, Krishnan P (2000) Vulnerability, seasonality and poverty in Ethiopia. J Dev Stud 36:25-53

Deressa T, Hassan R (2010) Assessment of the vulnerability of Ethiopian agriculture to climate change and farmers' adaptation strategies. PhD edn, University of Pretoria, South Africa

Diao X, Kennedy A, Mabiso A, Pradesha A (2013) Economy wide impact of maize export bans on agricultural growth and household welfare in Tanzania: a dynamic computable general equilibrium model analysis. International Food Policy Research Institute (IFPRI)

Dickey DA, Fuller WA (1979) Distribution of the estimator for autoregressive time series with a unit root. J Am Stat Assoc 74 427-431

Dorosh PA, Dradri S, Haggblade S (2009) Regional trade, government policy and food security: recent evidence from Zambia. F Policy 34:350-366

Dorosh PA, Rashid S, van Asselt J (2016) Enhancing food security in South Sudan: the role of markets and regional trade. Agro-Ecosystems 47:697-707

FAO (Food and Agriculture Organisation of the United Nations) (2015) Detailed Trade Matrix. Available: http://www.fao.org/ faostat/en/\#data/TM [2019, 08/01]

Food and Agriculture Policy Decision Analysis Tool (FAPDA) (2017) [Homepage of FAO]. Available: http://www.fao.org/inaction/fapda/tool/index.html\#main.html [2017, 01/18]

Garforth C, Rehman T (2006) Research to understand and model the behaviour and motivations of farmers in responding to policy changes. Department for Environment, Food and Rural Affairs Research Project EPES 0405/17, University of Reading, England

Getnet K (2009) Optimising the policy cost of market stabilisation: which commodity matters most in Ethiopia? J Int Dev 21 : $362-378$

Granger CWJ, Newbold P (1974) Spurious regressions in econometrics. J Econ 2:111-120

Gurmu MY, Meyer F, Hassan R (2017) Modelling price formation and dynamics in the Ethiopian maize market. J Agric Sci Technol 19:1439-1452

Hill RV, Porter C (2017) Vulnerability to drought and food price shocks: evidence from Ethiopia. World Dev 96:65-77

Jayne TS (2012) Managing food price instability in east and southern Africa. GI F Sec 1:143-149

Johansen S, Juselius K (1990) Maximum likelihood estimation and inference on cointegration with application to the demand for money. Oxf Bull Econ Stat 52:169-210

Kassie M, Teklewolde H, Jaleta M, Marenya P, Erenstein O (2015) Understanding the adoption of a portfolio of sustainable intensification practices in eastern and southern Africa. L Use Po 42:400-411 
Kotevska A, Dimitrievski D, Erjavec E (2013) Partial equilibrium model as a tool for policy analysis in agriculture: an empirical evidence of Macedonia. Agriculture and Rural development - Challenges of Transition and Integration Processes

Lütkepohl H, Krätzig M (2004) Applied time series econometrics. Cambridge University Press

McKay A, Morissey O, Vaillant C (1998) Aggregate supply response in Tanzanian agriculture. J IntTra \& Eco Dev 8:107-123

Meyer F, Kirsten J (2010) Modelling the wheat sector in South Africa. Agrekon 44:225-237

Meyer F, Westhoff P, Binfield J, Kirsten JF (2006) Model closure and price formation under switching grain market regimes in South Africa. Agrekon 45:369-380

Minot N (2011) Transmission of World Food Price Changes to Markets in Sub-Saharan Africa. International Food Policy Research Institute (IFPRI), Washington, DC.

Minot N (2013) Grain export bans in theory and in practice draft policy note. International Food Policy Research Institute (IFPRI), Washington, DC

Minot N (2014) Food price volatility in sub-Saharan Africa: has it really increased? F Poli 45:45-56

Nogales EG, Fonseca J (2014) Institutional procurement of staples from smallholders: the case of purchase for progress in Ethiopia. FAO

Porteous OC (2012) Empirical effects of short-term export bans: the case of African maize. Working Paper, Dept of Agricultural Economics, University of California, Berkeley

Porter C (2012) Shocks, consumption and income diversification in rural Ethiopia. J Dev Stud 48:1209-1222

Rashid S (2011) Inter-commodity price transmission and food price policies: an analysis of Ethiopian cereal markets. IFPRI

Rashid S, Kindie G, Solomon L (2010) Maize value chain in Ethiopia, constraints and opportunities for enhancing the system. IFPRI Project paper, International Food Policy Research Institute

Rashid S, Minot N (2010) Are staple food markets in Africa efficient? Spatial price analysis and beyond. Food Security Collaborative Working Papers 58562, Michigan State University, Department of Agricultural, Food, and Resource Economics

Stephens CE, Mabaya E, von Cramon-Taubadel S, Barrett CB (2008) Spatial price adjustment with and without trade. Selected paper prepared for presentation at the American Agricultural Economics Association Annual Meeting, Orlando July 27-29, 2008

Thiede BC (2014) Rainfall shocks and within-community wealth inequality: evidence from rural Ethiopia. W Dev 64:181-193

Thiele R (2000) Estimating the aggregate agricultural supply response: a survey of techniques and results for developing countries. Kiel Institute for World Economics, Kiel

Tripathi A (2008) Estimation of agricultural supply response using cointegration approach. Indira Gandhi Institute of Development Research, Mumbai

United States Department of Agriculture (USDA) (2015) Commodity database. Available via http://apps.fas.usda.gov/ psdonline/psdquery.aspx. Accessed 24 Mar 2015

United States Department of Agriculture (USDA) (2017) Commodity database. Available: http://apps.fas.usda.gov/psdonline/ psdquery.aspx. Accessed 8 Jun 2016

Worku I, Dereje M, Minten B (2015) Synopsis: diet transformation in Ethiopia. Ethiopia Strategy Support Program (ESSP), Research Note 46, Addis Ababa

Yami M, Meyer F, Hassan R (2017) Testing price leadership in major regional maize markets in Ethiopia: implications for targeted market intervention. Agrekon 56:97-109

\section{Publisher's Note}

Springer Nature remains neutral with regard to jurisdictional claims in published maps and institutional affiliations.

\section{Submit your manuscript to a SpringerOpen ${ }^{\circ}$ journal and benefit from:}

- Convenient online submission

- Rigorous peer review

- Open access: articles freely available online

- High visibility within the field

- Retaining the copyright to your article

Submit your next manuscript at $\boldsymbol{\nabla}$ springeropen.com 